\title{
Effects of Sublethal Concentrations of Diazinon on Total Protein in Tilapia Fish (Oreochromis Niloticus)
}

\author{
A.A. Soyingbe ${ }^{1}$, O.O. Ogunyanwo ${ }^{1}$, T.B. Hammed ${ }^{2}$, and A.O. Adesope ${ }^{3}$ \\ ${ }^{I}$ Dept. of Environmental Health Sciences, Ogun State College of Health Technology, Ilese-Ijebu, Nigeria. \\ ${ }^{2}$ Alesinloye Market Environmental Health Project, Alesinloye Market, Jericho Road, Ibadan, Oyo State, \\ Nigeria. \\ ${ }^{3}$ Department of Medical Laboratory Sciences, Ogun State College of Health Technology, Ilese-Ijebu, Nigeria
}

\begin{abstract}
This study assessed the influence of organo-phosphorus (OP) Diazinon pesticide on adult tilapia fish (Oreochromis niloticus) in a semi static renewal bioassay for 30 days. Adult fish were acclimatized to laboratory conditions for 7 days and then exposed to varying sub-lethal concentrations of diazinon (1.0, 2.5, 5.0, 7.5 and $10.0 \mathrm{mg} / \mathrm{l}$ ) for 30 days and compared with control (untreated). Total protein was determined in plasma, muscle, gills, liver and kidney. The water quality used for the study showed pH 7.05, dissolved oxygen $6.7 \mathrm{mg} / \mathrm{l}$, temperature $26.0^{\circ} \mathrm{C}$, alkalinity $16.25 \mathrm{mg} / \mathrm{l}$, conductivity $106.12 \mathrm{ps} / \mathrm{cm}$ and turbidity $0.46 \mathrm{NTU}$. The $96 \mathrm{~h} \mathrm{LC} 50$ of diazinon was $7.65 \mathrm{mg} / \mathrm{l}$. At various concentration of diazinon, fish showed uncoordinated behaviour such as somersaulting, convulsion and erratic swimming. The levels of total protein in plasma was significantly lower $(P<0.05)$ in all test concentrations in comparison with the control; but no concentration-dependent among the various concentration of diazinon was observed. Conversely, protein concentrations in muscle, liver, gills and kidney decreased with increased concentration of diazinon $(P<0.05)$. It is concluded that protein concentrations in muscle, gill, liver and kidney are useful biomarkers of sub-lethal effects of diazinon in Oreochromis niloticus. Key words: Biomarkers, Diazinon, Oreochromis niloticus, Renewal bioassay, Sub-lethal effects, Total protein
\end{abstract}

\section{Introduction}

With advancement in technology, agrochemicals such as pesticides especially chlorinated hydrocarbons are considered as part of the integrated farming practice to protect crops and animals from insects, weeds and diseases [1]; wide spread use of pesticide in agriculture is now a worldwide phenomenon [2]. Also, the use of pesticides for effective pests control has generated a lot of concerns relating to public health and environmental pollution. [3]. This is because organophorus pesticides have fully replaced the persistent chlorinated pesticides in the 1970's and on the beginning of 1980's. The main advantage of the organophosphorus pesticides was their low cumulative ability and short-term persistence in the environment. Although the organophosphorous pesticides have been replaced by pyrethroid base pesticides during the last 1015 years, there is still a very intensive utilization of organophosphates.

Apart from their regular use for crop production, organophosphorus pesticides are also utilized in fish culture (mainly those based on dichlovos and trichlorfon) to suppress some parasitary diseases such as monogeneoses and arthropodoses $[4,5]$. Nevertheless, the pesticide preparations are considered harmful for fish in most cases [6]. The aquatic ecosystem as a greater part of the natural environment is also faced with the threat of a shrinking genetic base and biodiversity due to indiscriminate use of pesticides. There are four major routes through which pesticides reach the water; it may drift outside of the intended area when it is sprayed, it may percolate or leach through the soil, it may be carried to the water bodies as run off, it may also be spilled through accidental discharge or neglect [7].

According to Mellandy [8], pesticides become readily available in the food chain through bioaccumulation in both aquatic and terrestrial flora and fauna that usually result into unquantifiable disastrous consequences on the ecosystem [9]. Due to the residual effects of pesticides, important organs like kidney, liver, gills, stomach, brain, muscles and genital organs are damaged in fish [7]. Diazinon is a common active substance of organophosphrous pesticides [10] and is an anticholinesterase which causes loss of functional coordination that result in immobilization of organisms [11].

\section{Materials and methods}

Fish samples used for this study were sourced from Agriking Farm Nig. Ltd, Abeokuta, Nigeria. They were transported to the Laboratory of Department of Environmental Health Sciences, Ogun State College of Health Technology, Ilese-Ijebu, Nigeira, where the study was carried out (Plate 1). The sample of Diazion was obtained from International Institute of Tropical Agriculture (IITA), Ibadan, Nigeria. Fifty-eight Oreochromis niloticus (mean weight $40.12 \pm 0.12 \mathrm{~g}$; mean length $10.24 \pm 0.4 \mathrm{~cm}$ ) were acclimatized individually in rectangular aquaria for seven days during which they were fed twice a day with $40 \%$ crude protein. 
Unconsumed feed and feacal waste were removed and water was regularly replenished as recommended by Oyelese and Faturoti [12]. Sub-lethal concentrations of diazinon for assay $(1.0,2.5,5.0,7.5$ and $10.0 \mathrm{mg} / \mathrm{l})$ were determined based on the range finding test [13]. These were prepared by transferring $0.02 ; 0.13,0.25,0.37$ and $0.5 \mathrm{ml}$, respectively of the original concentration of diazinon and making it up to $30 \mathrm{~L}$ with distilled borehole water in the test aquaria. Also, 30L of the diluents water was used as control. Four replicates of each treatment level (concentration) and control were set up and fishes were introduced individually into each aquarium.

The exposure period lasted for 30days during which the exposure media were renewed daily. The water quality parameters such as $\mathrm{pH}$, dissolved oxygen, temperature, alkalinity; conductivity and turbidity of the test media were determined and recorded following the standard method on water quality assessment, [14]. After the 30 day exposure period, blood samples for biochemical analysis were collected from each fish with 23G size needle and syringe. Fish were not fed prior to blood sample collection. Samples were preserved in heparinsed bottles. Fishes were sacrificed after blood collection and dissected for the collection of their gills, liver, kidney and muscle. Thereafter, $0.5 \mathrm{~g}$ of each organ was macerated (grounded) with pestle and mortar. Physiological saline was used for preservations and stabilization. Samples were centrifuged at the rate of $300 \mathrm{rpm}$ for 10 minutes. The supernatants were then removed and stored in plain bottles at $-20^{\circ} \mathrm{C}$ for analysis of the total protein levels (Lowery et al; 1951). The results obtained were subjected to Analysis of Variance (ANOVA), where difference exist, Duncan Multiple Range Test (DMRT) were used to test for pair wise significant differences $(\mathrm{P}<0.005)$ between treatments [15].

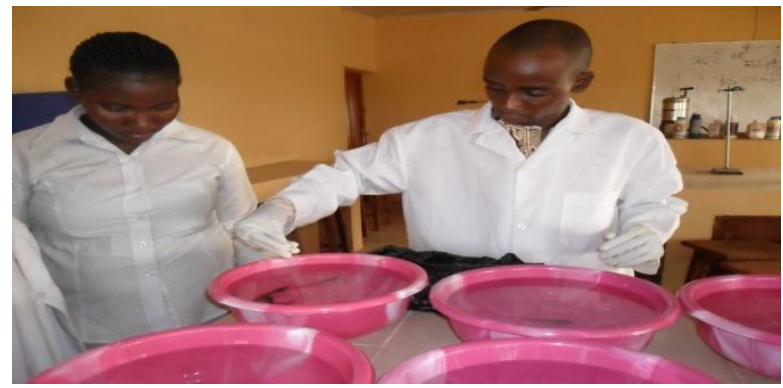

Plate 1: The researchers (led by Soyingbe A.A.) acclimatizing the fish samples in the Laboratory

\section{Results}

The results obtained from water quality analysis in this experiment showed the following: $\mathrm{pH}$ (7.05), Dissolved Oxygen $(6.7 \mathrm{mg} / \mathrm{l})$, temperature $\left(26.0^{\circ} \mathrm{C}\right)$, alkalinity $(16.25 \mathrm{mg} / \mathrm{l})$, conductivity $(106.12 \mathrm{us} / \mathrm{cm})$ and turbidity (0.46NTU). Total Protein in concentrations (mean) in plasma and organs of $O$. niloticus exposed to sub-lethal concentrations of diazinon for 30days were shown in the Table 1. The total protein in the analyzed samples, including plasma, muscle, liver, gill and kidney in the treatments were significantly higher than the values obtained for the control $(\mathrm{P}<0.05)$. Also, the treatments did not have significant impact on the level of protein in plasma and muscle of $O$. niloticus. That is, no concentration dependent pattern was observed in the plasma protein levels. However, a concentrations dependent effect was found in the protein profile in muscle, liver, gills and kidney with a progressive decrease in the concentration of proteins in these organs as diazinon concentrations increases.

Table 1: Total Protein Concentrations (mean) in Plasma and Organs of $O$. niloticus

\begin{tabular}{|l|l|l|l|l|l|}
\hline Treatments mg/l & Plasma & Muscle & Liver & Gill & Kidney \\
\hline $\mathrm{O}($ Control $)$ & $500^{\mathrm{a}}$ & $210.12^{\mathrm{a}}$ & $240^{\mathrm{a}}$ & $280^{\mathrm{a}}$ & $250^{\mathrm{a}}$ \\
\hline 1.0 & $360^{\mathrm{b}}$ & $160.01^{\mathrm{b}}$ & $190^{\mathrm{b}}$ & $210^{\mathrm{b}}$ & $160^{\mathrm{ab}}$ \\
\hline 2.5 & $300^{\mathrm{b}}$ & $140.03^{\mathrm{b}}$ & $150^{\mathrm{bc}}$ & $180^{\mathrm{bc}}$ & $140^{\mathrm{b}}$ \\
\hline 5.0 & $320^{\mathrm{b}}$ & $120.02^{\mathrm{b}}$ & $100^{\mathrm{cd}}$ & $150^{\text {cd }}$ & $120^{\mathrm{b}}$ \\
\hline 7.5 & $330^{\mathrm{b}}$ & $100.21^{\mathrm{b}}$ & $50^{\mathrm{d}}$ & $140^{\mathrm{de}}$ & $100^{\mathrm{b}}$ \\
\hline 10.0 & $350^{\mathrm{b}}$ & $90.12^{\mathrm{b}}$ & $50^{\mathrm{d}}$ & $130^{\mathrm{e}}$ & $90^{\mathrm{b}}$ \\
\hline
\end{tabular}

Mean followed by the same letter do not differ significantly, $(P<0.05)$ using DMRT.

The LC50 and LC5 values of Diazion on tilapia at the respective intervals are given in Fig.1. The 96h LC50 is basic value in the acute toxicity test. In the study, for adult tilapia (Orechromis niloticus), the 96hLC50 value was $7.65 \mathrm{mg} / 1$. 


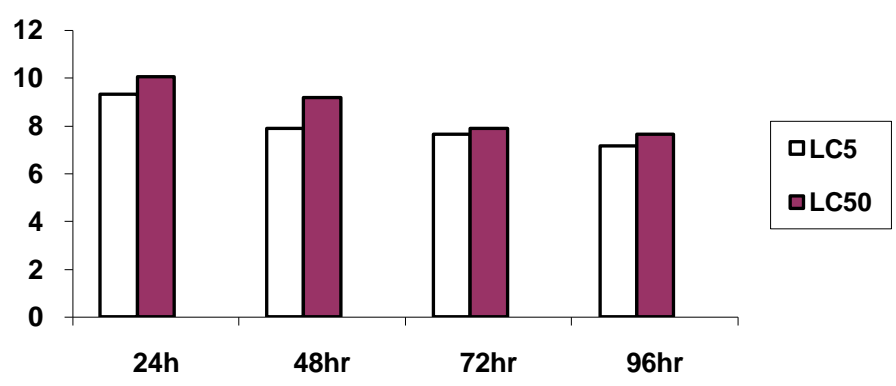

Fig 1: Acute toxicity test of diazinon in tilapia (Range means $95 \%$ confidence interval)

Sudden changes in the frequency of movement of the fish subjected to different concentrations of diazinon were physically observed. Behavioral changes like somersaulting, convulsion, excess secretion of mucus, erratic swimming, sudden quick movement and darkening of fish were observed during the exposure of fish to diazinon.

\section{Discussion}

The results of the media quality used in this study were within the optimal range reported in the previous studies $[16,13]$ as optimal requirement for most aquatic organisms. Thus, this suggested that the parameters did not seem to alter the toxicity of the insecticide to the test fishes. However, temperature, hardness, $\mathrm{pH}$, alkalinity, sex, age and other physiological status of the test animals were reported to have profound effects on the toxicity of agro-chemical $[17,18]$. Toxicity of diazinon to O. niloticus is relatively lower when compared with other species of fishes. The $96 \mathrm{hL} 50$ value $(7.65 \mathrm{mg} / \mathrm{l})$ obtained in this work was lower than the values reported in literature for other species of fish. For instance, Vittozzi and De-Angellis [19] summarized the 96hLC50 values of other organophosphate pesticides like parathion $(0.056-1.99 \mathrm{mg} / \mathrm{l})$, methyl parathion $(1.95$ $-8.91 \mathrm{mg} / \mathrm{l})$ and malathion $(0.091-22.9 \mathrm{mg} / \mathrm{l})$ for different species of fishes. These values indicated that these compounds were more toxic to fish than diazinon.

There are differences in the acute toxicity of diazinon for various fish species. The 96hLC50 values range in tenths to several tens of $\mathrm{mg} / \mathrm{l}$ [20]. In European eel (Anguilla anguilla) the 96hLC50 values range even in hundredths of $\mathrm{mg} / \mathrm{l}$ [20]. In their study, Oh et al. [21] presented three factors causing the selective toxicity of diazinon for various fish species. They were: different inhibition of actylcholine-sterase, different detoxification and absorption. This result agrees with the findings of Eisler [22] who reported the 96hLC50 of diazinon in Carassius auratus to be $9.0 \mathrm{mg} / \mathrm{l}$. It is also in consonance with $8.0 \mathrm{mg} / \mathrm{l}$ diazinon $96 \mathrm{hLC} 50$ value reported for Brachydanio rerio [23]. In contrary, the $96 \mathrm{hLC} 50(0.8 \mathrm{mg} / \mathrm{l}$ diazinon) for Cyprinodontid, (Poecilia reticulate) discovered by Keizer [23] was lower compared to what obtained in this result. Increase in physical activity, convulsion, excess secretions of mucus, erratic swimming sudden quick movement and darkening of fish was as a result of diazinon toxicity. This agrees with the findings of Alkahem [24] on Oreochromis niloticus exposed to trichloroform. Fafioye [25] reported similar observation in fish exposed to Parka bioglobosa and Raffia vinifera. Omitoyin et al. [26] also reported similar changes in Clarias gariepinus fingerlings exposed to lindane.

Rate of gill ventilation and oxygen consumption increases in fishes treated with sub-lethal concentrations of insecticides. Plasma proteins which include globulins, fiberinogens and albumins, serve a vital function in carrying materials from one part of the fish to another via circulation. They have nutritive, transporting, protective buffering and energetic functions. Comparing the plasma protein of fish in control treatment and other diazinon concentrations, a significant lower plasma protein levels were observed, indicating that at sub-lethal levels, the synthesis of protein was inhibited. Similar observation had been reported for diazinon in Clarias gariepinus [13]; DDT and malathion in Sarotherodon melanotheron [27]; and Cypermethrin in the Koren Rockfish, Sebasted schlegeli [28]. According to Das and Mukherjee [28], exposure of fish to most toxicants including pesticides for a longtime interferes with protein metabolism. This result is in agreement with the result of Inyang [13] who reported higher amount of plasma protein in control compared to other treatment concentrations of diazions. In this study concentration dependent effect was found in the protein profile in muscle, liver, gills and kidney with a progressive decrease in the concentration of proteins in these organs with increase in the concentration of diazinon. This is also in conformity with the findings of Inyang [13]. After 96h of exposure, diazion produced a significant decrease $(\mathrm{P}<0.05)$ in protein conceration in the blood plasma of experimental carp fish, as compared with the control group [29]. 


\section{Conclusion}

The results of this study indicate that diazinon exacts toxic effects on Tilapia fish (Oreochromis niloticus). The $96 \mathrm{hLC} 50(7.65 \mathrm{mg} / \mathrm{l})$ for adult Oreochromis nitoticus suggests that the fish show a quick response to the toxicant compared to other fishes. Even though aquatic organs can survive in small levels of pollutants their biochemical functions would be damaged regardless of how small these concentrations are. Protein levels in plasma of Oreochromis nitoticus could be a diagnostic tool but not necessarily good biomarker of xenobiotics. However, protein levels in muscle, liver, gills and kidney could serve as useful biomarkers of sublethal effects of diazinon.

\section{References}

[1] M.H. Akhtar, The Disposition of Bound 14c Agrochemical, 1986.

[2] T Saeed., W.N. Sawaya, N. Ahmad, S. Rajagopal and A. Al-Omair, Organophosphorus pesticide residues in the total diet of Kuwait. The Arab. J. Sci. Engr., 30, 2005, 17-27.

[3] E.V. Asogwa. and L.N. Dongo, Problems associated with pesticide usage and application in Nigeria cocoa production: A review. African Jour. of Agric. Research, .4(8), 2009, 675-683.

[4] J. E Noga, Fish disease. diagnosis and treatment., Mosby, St. Louis, 1995, 367.

[5] H. J. Schlotfeldt, D. J Alderman, What should I do? A practical guide for the freshwater fish farmer (Weymouth: Warwick Press, 2000) 60 .

[6] Z. Svobodov, B. Vykusov, and L. GROCH, Pesticides and fish poisoning. Agrochemicals and Animal Poisoning: Towards Toxicovigilance, IUTOX-Satellite Meeting, Lyon, 1998, 7.

[7] M. Z. Rahman, Z. Hossain, M.F.A. Mollah and G.U. Ahmed, Effect of diazinum 60 EC on Anabas testudineus, Channa punctatus and Barbodes gonionotus 'Naga'. The ICLARM Quarterly, 25, 2002, 8-12.

[8] K. Mellanby, "Pesticide and pollution". The fontana new naturalist (London and lasgow: Collins Clear-type press, 1967) $132-134$.

[9] G Terry, Breaking the pesticides Habit. Alternatives to 12 hazardous Pesticides. IASA publication, $1987,317$.

[10] T.R Roberts, and D.H. Hutson, Metabolic Pathways of Agrochemicals. Insecticides and Fungicides, Vol. 2 (Cambridge: The Royal Soc. Chem, 1998).

[11] G.T. Brooks, Penetration and Distribution of Insecticides. In: Wilkinson, C.F. (Ed.), Insecticide Biochemistry and Physiology, (Heyden, London, 1976) 3-60.

[12] O.A Oyelese, and E.O. Faturoti, Growth and mortality estimates in Clarias gariepinus fed graded levels of processed cassava peels. J. Trop. For. Resources, 11, 1995, 71-81.

[13] I.R Inyang, E.R. Daka and E.N. Ogamba, Changes in electrolyte activities of Clarias gariepinus exposed to diazinon. Biol. Environ. Sci. J. Trop., 7, 2010, 198-200.

[14] American Public Health Association (APHA), Standard methods for the examination of water \& wastewater. 21st edition, A.D Eaton, L.S Clesceri., E.W Rice, A.E Greenberg, M.A.H. Franson, (APHA, Washington, USA, 2005) 1976.

[15] T.A.T Wahua, Applied statistics for scientific studies (Ibadan: Africa Link Books, 1999).

[16] O.L Vittozzi, and G. De Angelis, A critic review of comparative acute toxicity of data on freshwater, Fish Aqua. Toxicol., 19, 1991, 167-204.

[17] C.E Boyd, Water Quality in Warm Water Fish Ponds. labama Agricultural Research Station, Alabama, $1979,362$.

[18] G.M Rand, and S.R. Petrocelli, Fundamentals of aquatic toxicology (Washington: Hemisphere Publishing Corporative, 1985 ) 666.

[19] O.L Vittozzi,. and G. De Angelis, A critic review of comparative acute toxicity of data on freshwater, Fish Aqua. Toxicol., 19, 1991, 167-204.

[20] E. Sancho, M.D Ferrando, E Andreau, and M. Gamon, Acute toxicity, uptake and clearance of diazinon by the European eel, Anguilla anguilla L. J. Environ. Sci. Health, Part B: Pestic., Food Contam., Agric. Wastes B27, 1992a, $209-221$.

[21] H. S Oh, S. K Lee, Y. H Kim. J. K Roh, Mechanism of selective toxicity of diazinon to killifish (Oryzias latipes) and loach (Misgurnus anguillicaudatus), Aquatic Toxicology and Risk Assessment. 14, 1991, 343-353.

[22] R Eisler, Diazinon hazards to fish, wildlife, and invertebrates: Asynoptic review. U. S. Fish Wildl. Serv., Biol. Rep. 85, $1986,37$.

[23] J. Keizer, DI Agostino, G., Vittozzi, L, The importance of biotransformation in the toxicity of xenobiotics to fish. 1. Toxicity and bioaccumulation of diazinon in guppy (Poecilia reticulata) and zebra fish (Brachydanio rerio), Aquat. Toxicol. 21, 1991, $239-254$.

[24] H.F Alkahem, Z. Ahmed, A.S. Al-Akel and M.J.K. Shamsi, Toxicity Bioasay and changes in haemotological parameter of Oreochromis niloticus induced by trichlorfom. Arab Gulf J,Scient. Res., 16, 1998, 581-593.

[25] O.O Fafioye, Lethal and sub lethal effects of extract of Parkia biglobosa and Raphia vinifera on some freshwater fauna. Ph. D. thesis, University of Ibadan, Ibadan, Nigeria, 2001, 216.

[26] Omitoyin. Utilization of poultry by products (feather and offals) in the diets of African catfish Clarias gariepinus (Burchell) Ph.D. Thesis, University of Ibadan, 1995, 219.

[27] K. Ramalingam, and K. Ramalingam, Effects of Sublethal levels of DDT, malathion and mercury on tissue proteins of Sarotherodon mossambicus (Peters), Proc. Indian A cad. Sci., Anim. Sci., 91, 1982, 50-505.

[28] L.H. Tee, F. Massoor and J. Kang. Responses of cypermethrin induced stress in haematological parameters of Koren Rockfish, Sebastes schlegeli, Aquac. Res., 36, 2005, 898-905.

[28] B.K. Das and S.C. Mukherjee. Sublethal Effect of quinalphos on selected blood parameters of Labeo rohita Ham) fingerlings, Asian. Fish. Sci., 13, 2000, 225-233.

[29] V. Luskova, M. Svoboda and J. Kolarova, The effects of diazinon on blood plasma biochemistry of carp (Cyprinus carpio) Acta. Vet. Bron., 71, 2002, 117-123. 